\title{
A new species of Actinopus (Mygalomorphae: Actinopodidae) from Bolivia
}

\author{
Duniesky RÍOS-TAMAYO \\ Unidad Ejecutora Lillo (UEL-CONICET), Miguel Lillo 205, 4000.S.M.Tucumán, Argentina. \\ E-mail. duniesky1979@gmail.com.
}

\begin{abstract}
A new species of the spider genus Actinopus Perty from Cochabamba, Bolivia is described under the name of Actinopus cochabamba sp. n. This is the second species of the genus described for the country. Detailed morphological description and illustrations of the new species are presented.
\end{abstract}

Key words: Actinopus cochabamba sp. n., Bolivia, Neotropical Region, Taxonomy, Trapdoor spiders.

Resumen: Una nueva especie de Actinopus (Mygalomorphae: Actinopodidae) de Bolivia. Se describe una nueva especie de araña del género Actinopus Perty de Cochabamba, Bolivia bajo el nombre Actinopus cocha$b a m b a$ sp. n. Esta es la segunda especie del género descripta para el país. Se presenta una detallada descripción morfológica e ilustraciones de la nueva especie.

Palabras clave: Actinopus cochabamba sp. n., Bolivia, Región Neotropical, Taxonomia, Arañas cavadoras.

\section{INTRODUCTION}

The family Actinopodidae is represented in Bolivia only by Actinopus wallacei PickardCambridge 1896. This species was originally described on the basis of a female specimen from Santarém, Pará, Brazil.

Half a century later, Schiapelli \& Gerschman (1945) described a male as A. wallacei based on a specimen collected by Dr. J. Vellard in Charamoco, Cochabamba, Bolivia.

Specimens observed by Schiapelli \& Gerschman (1945) are deposited in the Museo Argentino de Ciencias Naturales "Bernardino Rivadavia. This collection contains a vial with the label 778 "allotype ${ }^{7}$ " (Fig. 1), mentioned by Schiapelli \& Gerschmann (1945) as the male type, in addition to other vials preserving five females and two juveniles labeled by the authors as "A. wallacei". However, upon examination of the collection resulted that the vial labeled 778 "allotype $\widehat{ }$ " actually stored two females, but no male specimen.

Bücherl (1957) made comments on the copulatory bulb of $A$. wallacei on the basis of the observation of actual material. But it is unclear whether his observation was based on material collected from Brazil or based on the "allotype" specimen identified by Schiapelli and Gerschman.
Recently Miglio (2014) redescribed A. wallacei on the basis of female specimens from Santa Cruz, Boliva and provided pictures of the type specimen from Brazil in her unpublished doctoral thesis. Characteristics shown in photographs of the type examined by Miglio (2014) and of the specimen from Santa Cruz accord well with those of the original description in: the shape of spermathecae, an abundant number of retrolateral spines on tibia II, post-labial sigilla triangular and posterior ones elongated, converging into a small depression in the center of the sternum. These characteristics are very different from those found in the females present in the set referred to by Schiapelli \& Gerschman (1945).

The taxonomic revision of the genus Actinopus for Argentina allowed us to study hundreds of specimens of different collections. This facilitated the acquisition of experience regarding the morphological variability of the genus. The morphological differences mentioned above, the geographical distance (approximately $2000 \mathrm{~km}$ ) between the type locality of the female mentioned in Pickard-Cambridge (1896) and that of the male subsequently assigned in Schiapelli \& Gerschman (1945), and the distinct faunal differences between Cochabamba and Pará, all suggest that the identification made by Schiapelli \& Gerschman is incorrect. 




Fig. 1. Label on the vial MACN-Ar 778, probably handwritten by Rita Schiapelli.

Given the long distance between Santa Cruz (Bolivia) and Santarem (Brasil), as well as the faunal differences between the two localities, it seems possible that the specimens from Santa Cruz assigned to A. wallacei by Miglio (2014) are missidentified. However, the specimens of Actinopus cochabamba $\mathbf{s p .} \mathbf{n}$ clearly belong to a species different from the one studied by Miglio (2014), so that the correctness of Miglio's identification is not relevant in the present context. Thus, it seems undisputable that the females and the presumably lost male previously assigned to A. wallacei by Schiapelli \& Gerschman belong to a new species, described here as Actinopus cochabamba sp. $n$.

\section{MATERIAL AND METHODS}

All measurements are given in millimeters and were taken on the left side of the specimens. As standard in Araneae, total lengths were taken with chelicerae, and carapace lengths without chelicerae. Reference points for measurements followed Coyle (1974). All measurements were taken with a micrometric ocular on an Olympus SZ4045 stereoscope. The images were captured with a 2500 Moticam camera of $5.0 \mathrm{M}$ pixel coupled to a stereoscopic MOTIC trinocular / SMZ-168. The notation for leg spines follows Goloboff \& Platnick (1987); variation in the sides of a specimen (in number of spines, cuspules, or teeth) is indicated as two numbers or formulae separated by a slash ("/"); when describing variation in chaetotaxy, only surfaces with different numbers of spines are listed.

The studied material is deposited in the Museo Argentino de Ciencias Naturales "Bernardino Rivadavia" (MACN, Cristina Scioscia). The following abbreviations were used in the text: AME $=$ anterior median eyes, $\mathrm{ALE}=$ anterior lateral eyes, $\mathrm{PME}=$ posterior median eyes, $\mathrm{PLE}=$ posterior lateral eyes, $\mathrm{D}=$ dorsal, $\mathrm{P}=$ prolateral, $\mathrm{R}$ $=$ retrolateral, $\mathrm{V}=$ ventral, $\mathrm{P} \mathrm{SUP}=$ prolateral superior, $\mathrm{P} I N F=$ prolateral inferior, $\mathrm{P} A \mathrm{INF}=$ prolateral apical inferior, $\mathrm{P} \mathrm{M}=$ prolateral medi- al, $\mathrm{D}$ ANT $=$ dorsal anterior, $\mathrm{D} \mathrm{B}=$ dorsal basal, $\mathrm{R}$ $\mathrm{SUP}=$ retrolateral superior, $\mathrm{R} \mathrm{INF}=$ retrolateral inferior, $\mathrm{V}$ ANT $=$ ventral anterior, $\mathrm{V}$ POST $=$ ventral posterior, $\mathrm{V} A=$ ventral apical, $1: 2 \mathrm{~A}, 3: 4$ $\mathrm{B}=$ indicate that the spines referred to are in the apical half or basal third-fourth.

\section{TAXONOMY}

Familia Actinopodidae Simon, 1892

Género Actinopus Perty, 1833

Actinopus cochabamba sp. $n$.

(Figs. 2A-E)

Actinopus wallacei: Schiapelli \& Gerschman, 1945: 167, pl. I (D^̋).

Diagnosis. Actinopus cochabamba sp. n. can be distinguished from A. wallacei by the shape of their spermathecae (Fig. 2E), the lower number of retrolateral spines on tibia II (Fig. 2C), the flat center of the sternum, and the squared shape of the post-labial sigillum, the posterior ones being smaller (Fig. 2B).

Type material. Holotype: Bolivia. Cochabamba, Charamoco. Dec 1941. Coll. J. Vellard. 1 q (MACN-Ar 778) [17³6' S 66¹6' W]. Paratypes: Same locality, 3 우 (MACN-Ar 777), 1 ㅇ (MACNAr 35350).

Etymology. The specific name is a noun in apposition taken from the type locality.

Description. Female (Holotype): Total length: 20.16. Carapace (Fig. 2A): length 7.68, width 7.68, with lateral marginal bristles until coxae III, 15 on each posterior margin. Cephalic region: length 4.80 , width 6.24 , clypeus with 25 bristles, 2 between AME-ALE, 20 between PME-PME, 14 bristles behind each diad PMEPLE and 5-9 bristles between ALE-PLE. Fovea narrow: length 1.08, width 2.40. Eyes: diameters and interdistances: AME 0.20, ALE 0.52, PME 0.32, PLE 0.32, AME-ALE 1.00, PME-PLE 0.36, AME-PME 0.60, ALE-PLE 0.72, AME-AME 0.44, ocular group length 1.32 , anterior width 3.72 , 3.60 posterior width. Chelicerae robust; length 4.68 , width 2.88 , with bands of internal dorsal bristles reaching the rastellum base. Cheliceral apex with 12-15 recumbent and elongated bristles covering the base of the fang; dorsal region with superficial grooves. Rastellum on a long projection with 11 marginal blunt cusps and 5 dorsal smaller ones. Cheliceral furrow with 5 large promarginal teeth, 6 retromarginal 



Figs. 2. A-E. Actinopus cochabamba sp. nov. A carapace, B sternum, C tibia II, retrolateral view D Addomen, ventral view, E spermathecae. Scales $=1 \mathrm{~mm}$. 
teeth and 12 denticles distributed throughout the furrow. Labium: length 1.68, width 1.56, with 27 anterior cusps. Maxillae: anterior length 2.28 , posterior length 2.88 , width 2.28 , with 80 cusps 1:3 V ANT, expanding to the anterior face. Sternum (Fig. 2B): length 5.76, maximum width 4.56 , minimum width 1.56 , center plane. Postlabial sigilla squared and deep; posterior sigilla small. Abdomen: length 10.80, globose, with darks bristles, longest on the dorsum. Posterior median spinnerets: length 0.96 ; posterior lateral spinnerets with basal: medial: apical article of lengths 1.00:0.40:0.28. Spigots: 3 large and 38 small ones on PMS; PLS, basal: medial: apical article with 4 large and 45 small: 2 large and 35 small: 2 large and 60 small. Length of legs and palpal segments (femora, patellae, tibiae, metatarsi, tarsi, total): I: $2.46,1.56,1.20,1.50$, $0.66,7.38$. II: $2.46,1.62,1.20,1.56,0.66,7.50$. III: $2.40,1.20,0.90,1.68,0.66,6.84$. IV: 3.00 , $1.68,1.50,1.80,0.66,8.64$. Palp: $2.28,1.50,1.50$, $-, 1.56,6.84$.

Chaetotaxy: All femora: 0. Patellae: I-II, 0; III, $10 \mathrm{P}+10$ on the margin, $7 \mathrm{R}(1: 2 \mathrm{~A})+9$ on the margin; IV, 10 P SUP-D ANT; palp, 1-1-1-1-1 P. Tibiae: I, 5 P (1/2 A), 1-1 V POST, 2-5 R INF; II, $37 \mathrm{R}(3: 4 \mathrm{~A}), 1-1 \mathrm{v}$ post; III, $1 \mathrm{D} \mathrm{B}$, a crown of 23 thorns, $19 \mathrm{R}$; IV, 2 P A, 1 D A; palp, $10 \mathrm{P}$ (serial), 19 R INF. Metatarsi: I, 21 P INF, $22 \mathrm{R}$ INF, 1-1-1 V POST; II, 21 P INF, 20 R INF, 1-1-2 V POST; III, 4/2 D B, 27 on row D POST-R (more abundant R A); IV, 1-4-2-4 P. Tarsi: I, 9 P INF, 15 R INF, 2 V A; II, 13 P INF, 10 R INF, 2 V A; III, 20 R, 19 V-P; IV, 28 V-P; Palpo, 15 P (serial), 20 R INF (serial). Total number of $\mathrm{R}$ thorns on tibiae I y II (Fig. 2C): 7 y 37 respectively. Coxae I y II with slightly projected anterior angle.

Trichobothria: Tibiae (two rows: P-D and R-D): I 5-5; II 5-6; III 5-4; IV 6-5. Metatarsi: (dorsal row in zig-zag) I 11; II-III 9; IV 8. Tarsi: I 10; II 9; III 7; IV 9. Color: carapace reddish brown, chelicerae darker on apical region. Abdomen light brown; lungs with light markings (Fig. 2D); sternum, labium and maxillae light yellow; spinnerets yellow. Legs light reddish brown.

Male. Described by Schiapelli \& Gerschman (1945) as the male of Actinopus wallacei.

Distribution. Known only from the type locality.

Other specimens examined. BOLIVIA: Cochabamba, Charamoco, Dec 1941. Col. J. Vellard. 3 immatures (MACN-Ar 777).

\section{DISCUSSION}

Actinopus cochabamba sp. n. is the second species of the genus described for Bolivia. The morphological comparisons between the female type of Actinopus wallacei, the Bolivian specimens from Santa Cruz described by Miglio (2014) and the females referred to in Schiapelli \& Gerschman (1945), showed important differences. The females from Cochabamba, presented here, have simple spermathecae without lobes (Fig. 2E), a scarce number of retrolateral spines on tibia II (37, Fig. 2C), and a post-labial square sigillum, being the posterior ones short (Fig. 2B). These characteristics differ from those of the female described by Pickard-Cambridge (1896) and those of the female from Santa Cruz studied by Miglio (2014).

In the future, if the male belonging to the species A. cochabamba sp. n. is found again, it would be interesting to corroborate the presence of a square post-labial sigillum and small posterior ones (as in the female; these characters were not described by Schiapelly \& Gerschman for the male). It is also expected that the copulatory bulb is slender and elongate, in correspondence with the elongate shape of female spermathecae - this general correspondence between bulbs and spermathecae has been observed in others species of the genus present in Argentina (D. Ríos \& P. Goloboff, unpublished data).

\section{ACKNOWLEDGMENTS}

This work was supported by a CONICET, scholarship. Special thanks to Martín Ramírez and Cristian Grismado (MACN) for lending specimens. To Pablo A. Goloboff and Cristian Grismado for improving the manuscript and the translation of the draft. Finally, I thank the reviewer Martín Ramirez for his corrections.

\section{BIBLIOGRAPHY}

Bücherl, W. 1957. Sôbre a importância dos bulbos copuladores e das apófises tibiais dos machos na sistemática das aranhas caranguejeiras (Orthognatha). Anais da Academia Brasileira de Ciências, 29: 377416

Coyle, F. A. 1974. Systematics of the trapdoor spider genus Aliatypus (Araneae: Antrodiaetidae). Psyche, 81: 431-500.

Goloboff, P. A. \& Platnick, N. I. 1987. A review of the Chilean spiders of the superfamily Migoidea (Araneae, Mygalomorphae). American Museum Novitates, 2888: 1-15. 
Miglio, L. 2014. Revisão Taxonômica do Gênero Actinopus Perty, 1833, com a descrição de quatro espécies novas de Missulena Walckenaer, 1805 (Araneae, Mygalomorphae, Actinopodidae). Dissertação (Doutorado) - Universidade Federal do Pará.

Perty, M. 1833. Arachnides Brasilienses. In: de Spix, J. B. \& Martius, F. P. (eds.) Delectus animalium articulatorum quae in itinere per Braziliam ann. 1817 et 1820 colligerunt. Monachii, pp. 191-209, pls. 38-39.

Pickard-Cambridge, F. O. 1896. On the Theraphosidae of the lower Amazons: being an account of the new genera and species of this group of spiders discovered during the expedition of the steamship "Faraday" up the river Amazons. Proceedings of the Zoological Society of London, 1896: 716-766.

Simon, E. 1892. Histoire naturelle des araignées. Paris $1,1-256$.

Schiapelli, R. D. \& Gerschman, B. S. 1945. Parte descriptiva. In: Vellard, J., R. D. Schiapelli \& B. S. Gerschman (eds.) Arañas sudamericanas coleccionadas por el Doctor J. Vellard. I. Theraphosidae nuevas o poco conocidas. Acta Zoologica Lilloana $3,165-213$.

Doi: 22179/REVMACN.18.444

Recibido: 5-IV-2016

Aceptado: 27-X-2016 